$K \& K$ ANMELDELSER

\section{Charlotte Engberg}

\section{Billedstormer}

Alice Andersen: Konnets astetik. Aarhus Universitetsforlag. 1989.

Der var engang, hvor feminister så det som deres primare opgave at danne fælles front mod, hvad man kaldte for kulturens "falske kvindebilleder«. Det var også dengang, hvor man ikke kunne opspore et eneste spejl på $\emptyset$ lejrene. Med en larmende gestus knuste man alle spejle ud fra et ræsonnement, der lød nogenlunde som følger: kvinder skal ikke spejle sig, for det billede der møder dem i spejlet er ikke dem selv, men snarere forestillingen om dem selv, en forestilling som er iscenesat af et patriarkalsk samfund. Kun ved at knuse spejlet og istedet spejle sig $\mathrm{i}$ hinanden kan kvinder frigøre sig og finde frem til deres egen sande identitet.

Udover en næsten rørende tro på, at undertrykkelsen sidder $\mathrm{i}$ spejlet eller $\mathrm{i}$ tojet eller i noget andet man kan vorlge enten at if $ø$ re sig eller netop undlade at tage på sig, illustrerer ovenstående eksempel også en ganske bestemt - og på et vist tidspunkt meget udbredt forestilling inden for kvindebevægelsen om forholdet mellem krop, køn og identitet. Altså forestillingen om sand versus falsk identitet, om den nøgne krop som bærer af sandheden og den påklædte krop som falsk eller undertrykt. Og måske vigtigst af alt; at kvinder ved at spejle sig i hinanden kan eliminere eller undgå det maskuline blik og de forestillinger, der knytter sig til det.

»Lille spejl på vaggen dér, hvem er smukkest $\mathrm{i}$ verden hér?«. Som man vil vide, er det ikke fra spejlet, man skal høre sandheden. Men på den anden side er der ikke noget andet sted at henvende sig - med hensyn til sandheden. Ifølge den franske psykoanalytiker Jacques Lacan danner mødet mellem subjektet og spejlet - det forhold at man automatisk påtager sig spejlets billede af een selv - udgangspunkt for alle senere identifikationer. I artiklen om »Spejlstadiet « ${ }^{1}$ gør Lacan rede for, hvordan det lille barn spejler sig i den anden, hvad enten denne anden er en konkret person eller netop et spejlbillede, og at denne spejling er en forudsætning for dannelsen af »jeginstansen «. Men denne »jeg-instans « befinder sig herefter $i$ en "fiktiv dimension«, som Lacan formulerer det. Fiktiv for så vidt som subjektet aldrig kan falde sammen med sit spejlbillede, hvilket i sproget kan eksemplificeres ved forskellen mellem jeg og mig (»jeg ser mig i spejlet«).

»Ved gentilegnelsen af mødet mellem biologi og symbolicitet i kvindekropppen, er en vigtig betingelse opfyldt for, at en ny frigjort imagineret kvindelighed kan opstå. Først når kvinderne udfra deres egne kroppe kan genspejle deres suveræne kvindelighed og derudfra indlevende genspejle det mandlige, er en vigtig betingelse til stede for ..."

Citatet stammer fra Alice Andersens magisterkonferensspeciale, der nu foreligger som bog under titlen Kфnnets cestetik - bidrag til en "betydelse" of $k$ vindeligheden, og er et godt eksempel 
på den særlige tone, der hersker. $N$ år Alice Andersen taler om at kunne »genspejle« en »suveræn kvindelighed« ud fra ens egen krop, giver hun udtryk for forhåbninger om, at kvinder ideelt set har adgang til en ubesmittet, autentisk kvindelighed, hvis bare de rette betingelser er til stede. Her forklares betingelserne som »gentilegnelsen af mødet mellem biologi og symbolicitet«. Eller måske peger Alice Andersen på nødvendigheden af at tilegne sig kroppen igen? Her som andre steder $i$ afhandlingen stiller selve fremstillingen sig i vejen for en forståelse af, hvad det egentlig er forfatteren mener.

Det gælder generelt for kvindeforskningen, at den har været optaget af to projekter: på den ene side at rekonstruere en kvindelig tradition, det være sig inden for historien, litteraturen eller som i dette tilfælde billedkunsten, og på den anden side at genfortolke eller genlase, som det hedder med et begreb hentet fra feministisk litteraturvidenskab - de beskrivelser og forestillinger der knytter sig til de kulturelt bestemte fantasier om det kvindelige (og måske $\mathrm{i}$ anden række: det mandlige).

Alice Andersen er mest interesseret i den sidste type projekt. Hun tager udgangspunkt i det forhold, at billedkunsten er fuld af kvinder, men de kvinder vi møder dér, eller mere generelt - den fremstilling af kvindeligheden vi dér konfronteres med - er ikke formuleret af kvinderne selv. Det der præger billedet er en »mandligt imagineret kvindelighed «, som det hedder med henvisning til den tyske litteraturforsker Silvia Bovenschen, som i Danmark først og fremmest er kendt for sin artikel $\gg$ Gibt es eine Weibliche »Ästhetik«« fra 1976. Eller med Alice Andersens karakteristiske sprogbrug: »Går vi ud fra den antagelse, at mændene og det mandlige, gennem udvælgelse, skabelse og mærkning af kulturudtrykkene bestemmer, hvad der lader sig sige i relation til objektive og almene forhold, lader det sig gøre at belyse kvindeligheden udfra to hovedsynsvinkler. Kvindernes egen, der indeholder den nye indsigt, om usynligheden og derudover er stumhedens og privathedens synsvinkel, der kaster kvinderne tilbage $\mathrm{i}$ deres »sprogløse kroppe«, og som den anden synsvinkel: bestemmelsen af kvinderne som $\gg$ det andet $k \varnothing n$ «, og som sådant synliggjort af en mandligt normeret symbolicitet«.

Jette Lundbo Levy har i sin bog om Victoria Benedictsson, ${ }^{2}$ også fors $\emptyset \mathrm{gt}$ sig med hypotesen om et dobbeltblik, hvorved man altså skulle kunne skeIne mellem, hvad Bovenschen ville kalde for en »mandligt imagineret kvindelighed« og - går jeg ud fra - en »kvindeligt imagineret kvindelighed «. Men spørgsmålet er imidlertid, om en sådan skelnen overhovedet er mulig. Om det ikke snarere er sådan, at vi i det store og hele deler hinandens syn og dermed de fantasier, der knytter sig til henholdsvis det mandlige og det kvindelige. Altså at mandens syn på $k v i n d e n$ samtidig også er kvindens syn på sig selv - og vice versa. $O g$ det uanset hvor lidet flatterende disse fantasier end måtte være. I en fallogocentrisk tænkning som vor, er kvinden placeret som »det andet $k \varnothing n \ll ; ~ u d-$ fordringen ligger for mig at se mere $i$ at vise, hvordan det lader sig gøre at 
opretholde denne forestilling, end at negere dette irriterende forhold.

Afhandlingen s $\varnothing$ ger at vise, hvordan man i den neolitiske, forhistoriske periode kan finde eksempler på beskrivelser af kvindekroppen som magtog betydningsfuld. Dette tidlige stadie i menneskehedens historie parallelliserer Alice Andersen med den individuelle livshistories praødipale periode. Herefter bevager argumentationen sig ind på psykoanalysens gebet; Freud er i skudlinien og Andersen henter ammunition hos bla. Julia Kristeva og Janine Chasseguet-Smirgel. Det er desuden een af afhandlingens pointer, at der er tale om en renaissance for denne forhistoriske periode, som ifølge afhandlingens tese bl.a. er kendetegnet ved »den primitive symbolske moders kvalitative rumlige omverdensrelation«. Her nævnes i den forbindelse symbolisternes ambivalente fremstillinger af dæmoniske og fascinerende kvinder, og hvordan disse forestillinger gentages hos Picasso og $\mathrm{i}$ Cobra-skolens billeder.

Afhandlingen bringer $i$ det hele taget mange interessante diskussioner på bane. Der er tale om et ambitiøst værk, som foruden inddragelse af den klassiske kunstkritik lægger vejen rundt om psykoanalysen og feministisk kunst- og litteraturkritik. Centralt $i$ afhandlingen står den tyske kunsthistoriker Peter Gorsen og hans androgyne utopi. Det er ligeledes med henvisning til ham, at Andersen beskriver kvindeligheden som usynligt og stumt til stede i billedkunsten.

Det bringer afhandlingen ud i nogle temmelig spekulative betragtninger over - på den ene side - hvorfor kvin- deligheden har indtaget denne position og - på den anden side - hvilke muligheder der måske alligevel eksisterer for at kvindeligheden kan komme til orde. Eller som Alice Andersen manende formulerer det: »Udfoldelsen af en kvindelig kompetance $i$ en kreativ praksis må $\mathrm{i}$ den forbindelse ses fra to sider; på den ene side består den $\mathrm{i}$ at søge et kvindeligt indhold, et alternativt formsprog, på den anden side består den $\mathrm{i}$ at indoptage det mandlige og udtrykke det under en kvindelig kompetance

Denne opfattelse af kvindeligheden som usynlig og stum bringer mindelser om hin overophedede kvindesprogsdebat, som hærgede landet for et par år siden. Her gav man udtryk for samme optimistiske forhåbninger om, at der »bag《 det prosaiske, dybest set kvindeundertrykkende hverdagssprog, kunne befinde sig et andet sprog, som langt bedre formåede at bringe kvindeligheden til udtryk.

En lignende oprindelsesontologi $\mathrm{g} \emptyset \mathrm{r}$ sig galdende i Konnets astetik og kaster et anakronistisk skær ind over hele projektet. Dette i kombination med - og disse ting følges tit ad - en moraliserende normativ tone, gør afhandlingen til et trættende bekendskab uagtet de mange relevante spørgsmål, der stilles til kunstkritikken i almindelighed og kvindeforskningen i særdeleshed.

1. Jacques Lacan: »Spejlstadiet « In: Det Ubevidste sprog, København 1973, Rhodos

2. Jette Lundbo Levy: Dobbeltblikket At beskrive kvinder, København 1980, Tiderne Skifter. 